\title{
Assessing the integration of gays and lesbians into the South African National Defence Force
}

\author{
Aaron Belkin and Margot Canaday ${ }^{1}$
}

\begin{abstract}
During the apartheid era, the South African military maintained a dual policy on homosexuality - prohibited among members of the permanent force, homosexuality was officially tolerated among conscripts. When the regime fell, the new government committed itself to human rights considerations, and after the South African Constitution adopted a provision of non-discrimination on the basis of sexual orientation in 1996, the South African military followed suit. In 1998, the South African National Defence Force (SANDF) implemented the Policy on Equal Opportunity and Affirmative Action that declared that there would no longer be discrimination against gays and lesbians. This article draws together military and government documents, secondary research, press coverage and interviews with individuals with knowledge on this topic to assess the effects of this policy change. The evidence suggests that the integration of gay and lesbian personnel has not had a negative impact on recruitment and retention, morale, unit cohesion or operational effectiveness in the SANDF.
\end{abstract}

\section{Introduction}

During the apartheid era, the South African military maintained a dual policy on homosexuality - prohibited among members of the permanent force, homosexuality was officially tolerated among the conscript force to prevent malingering. However, official toleration was accompanied by aversion shock therapy, chemical castration and other human rights abuses against gay and lesbian personnel, which have only recently come to light in the new South Africa. When the apartheid regime fell in 1994, the new democratic government committed itself to addressing human rights considerations, including the status of gays and lesbians. After the South African Constitution adopted a provision of non-discrimination on the basis of sexual orientation in 1996, the South African military followed suit. In

\footnotetext{
${ }^{1}$ We thank Justine Navarrette for her outstanding research assistance.
} 
1998, the South African National Defence Force (SANDF) implemented the Policy on Equal Opportunity and Affirmative Action (South African Department of Defence 2002a) that formally declared that there would no longer be discrimination against gays and lesbians in the armed services and that the military was officially uninterested in the sexual orientation of any of its service members, be they gay or heterosexual.

\section{Methodology}

This article draws together military and government documents, secondary research and press coverage along with 26 interviews with individuals with knowledge on this topic to assess the effects of this policy change. The information collected was systematically gathered from publicly available primary and secondary sources relevant to an understanding of military outcomes associated with homosexual service in the SANDF. Sources and methods included identification, retrieval and analysis of prior research bearing on homosexual service in the SANDF conducted by governmental, academic and policy-focused organisations in South Africa. Interviews were held with relevant SANDF units and major academic, non-governmental and policy observers familiar with gay-military issues in South Africa since the ban was lifted.

This article relies on a multi-method approach to compare and synthesise evidence provided by a variety of sources in order to draw conclusions. Whenever possible, independent observations from multiple sources are compared to draw out common findings that are consistent among observers in different sectors (e.g. military, academic, non-governmental). During the interview process, we also sought to ensure that the universe of sources drawn upon for the study was complete by asking expert observers from different sectors for recommendations of additional sources of information. The final compilation of sources that informs this article thus reflects a comprehensive search for relevant data and opinions.

\section{The apartheid military and homosexuality, 1948-1994}

By the mid-1960s, the South African military comprised of both a permanent and a conscript force. The conscript force comprised of approximately 27000 white men by 1970. (Black people were allowed to join the military in limited roles but were not conscripted and remained junior partners in defence.) After 1970, "annual intake figures could not be increased without extending conscription to non-whites", and so the period of conscription was gradually increased from three to nine to twelve months, until it finally reached two years (Cilliers\&Heinecken 2000:245). In 1990, the period of conscription was again reduced to one year. 
The military's policy on homosexuality has its origins in the system of conscription. As conscription became increasingly controversial by those opposed to or ambivalent about apartheid, military officials worried that an all-out ban on homosexuality might provide young, white South African men with a relatively easy way to avoid military service. Accordingly, a dual policy on homosexuality was developed soon after conscription was adopted in the mid-1960s. Homosexuality among the conscript force was officially tolerated, but gay conscripts were considered to have a 'behavioural disorder' and were not appointed to leadership positions or entrusted with sensitive information. According to Lindy Heinecken, a military scholar and one of the country's premier experts on gays in the SANDF, the general trend was "to place such persons in posts considered more suitable, such as catering or as medical orderlies" (Cilliers \& Heinecken 2000: 256). At the same time, homosexuality was strictly forbidden among members of the permanent force, and those who applied for the permanent force were routinely asked about homosexuality. If an individual's answers indicated that one was either a 'latent or practicing homosexual', the recruitment process was aborted. Further, permanent force members who committed homosexual acts could be punished up to court martial, while members who had committed no acts but who admitted homosexual tendencies were sent for rehabilitation (Heinecken 1998:7). ${ }^{2}$

While the military officially tolerated homosexuality among conscripts during the 1970s and 1980s, the culture of the military was often uncomfortable for gay and lesbian personnel from either the conscript or the permanent force. General Viljoen, Head of the Army, ordered in 1982 that "[a]ll possible steps must be taken to combat the phenomenon of homosexuality or lesbianism in the army" (Lewin 2001). South African scholars have commented on the development of a white militarism within the military, which depended on the idea that the South African troopie was the masculine defender of a threatened volk. The heroic discourse surrounding the troopie rested on notions of male dominance and on hostility towards gay men, who were viewed as a threat to the nation. White people who opposed conscription were branded 'gay' by the regime, reinforcing the notion that gays were enemies of the state (Conway 2002). ${ }^{3}$ Gay and lesbian conscripts were

${ }^{2}$ Statistics pertaining to the discharge of homosexuals from the permanent force of the former South African Defence Force (SADF) are not available from the military. It is believed that only a small number of gays and lesbians were actually discharged - it was far more likely for homosexuals to be vetted in the induction process or to be 'rehabilitated' if already in the force (Pollecut 2003; Reid 2002).

${ }^{3}$ For an elaboration on these ideas, see Conway (2000). 
thus subjected, as former conscript Matthew Krouse has observed, to "a form of hidden terrorism which permeate[d] every echelon of the military environment" (Krouse cited in Gevisser \& Cameron 1995: 211). According to the Aversion Project, an in-depth study of the treatment of homosexuals in the military, the environment that Krouse described went beyond mere harassment or job discrimination. As the Aversion Project documented, some gay and lesbian conscripts were subjected to routine humiliation, aversion shock therapy, chemical castration, hormonal and drug treatment and other abuses. "During basics, the humiliation of gays was very, very common. They were called awful names and were often made scapegoats," one conscript reported. Sometimes these gay scapegoats were beaten up by the rest of the unit "to build ... cohesion". Others told of sexual assault and coercion: "At Maritzkop camp . . . an [officer] forced [servicemen] to drop their trousers and commit 'indecent sexual acts' with each other". Another captain [suspected of homosexuality] "was stripped of his medals with a bayonet, and his troops had to trample on them" (Van Zyl et al. 1999, Chapter 4).

"Even while officially tolerated, gay and lesbian personnel were also sent to psychiatric units where 'psychiatrists' were experimenting with aversion therapy on 'patients' who, other than being labelled homosexual, were healthy." According to the Aversion Project report,

[e]lectrodes were strapped to the arms of the subject, and wires leading from these were in turn connected to a machine operated by a dial calibrated from one to ten. The subject was then shown black and white pictures of a naked man and encouraged to fantasize. The increase in the current would cause the muscles in the forearm to contract - an intensely painful sensation. When the subject was either screaming with pain, or verbally requested that the dial be turned off, the current would be stopped and a color Playboy centerfold substituted for the previous pictures. . . This process would be repeated three times in a single session. Sessions were held twice daily for 3 to 4 days. People subjected to this therapy experienced long periods of disorientation afterwards. (Van Zyl et al. 1999, Chapter 4)

Another informant reported seeing a woman undergo electric shock so powerful that her shoes flew off of her feet (Van Zyl et al. 1999, Chapter 4). In addition to the evidence offered by the Aversion Project report, more recent revelations have been made that offer prima facie evidence of a 'sexual realignment programme' in the military during the 1970s and 1980s. Some gay and lesbian 
personnel who could not be 'cured' by drugs or aversion therapy were given sexchange operations by medical staff. The Aversion Project also reported the use of chemical castration on homosexual personnel. While castration, aversion shock therapy, hormonal and other drug treatment and sex change operations may not have been a systematic policy during the 1970s and 1980s, "the fact that it could happen", according to Aversion Project investigator Graeme Reid, "shows something about attitudes towards gays at that time" (Reid 2002).

\section{The emergence of the SANDF and the new policy on sexual orientation}

After years of external and internal pressure, the apartheid system began to crack in the early 1990s. In 1993, the United Nations assisted in negotiations between the ANC and apartheid officials as part of the Convention for a Democratic South Africa (CODESA). A year later, multiparty elections were held, which brought the ANC to power, and a provisional constitution was drafted that established South Africa as a non-racist and democratic state (South African Commission on Human Rights 1999).

The groundwork for the inclusion of a gay rights provision in the Constitution had been laid in 1992, when gay activists persuaded the (then exiled) ANC to adopt a policy on sexual orientation. Initially, the ANC considered the issue irrelevant. A member of the National Executive Committee famously remarked in 1987: "We don't have a policy on flower sellers either", further commenting that "if everyone was like that, the human race would come to an end". Activists publicised the statement and were then able to get the ANC to recognise gay and lesbian rights (Cock 2002). The Democratic Party and the Inkatha Freedom party - other major players in South African politics - similarly each took a pro gay rights stance (Sanders 1997:105).

As a result of this political support, sexual orientation was included in the draft Constitution when the ANC first came to power in 1994. Committed to a democratic process, the new government invited feedback on the draft Constitution from the public, who could submit feedback in either written or oral form. The process was planned, according to sociologist and military expert Jacklyn Cock, "as participatory, consultative, and representative" (Cock 2002:9). A gayrights organisation, the National Coalition for Gay and Lesbian Equality (NCGLE), was formed in 1994 to lobby to retain the gay rights provision in the final Constitution. NCGLE allied itself with a consortium of trade unions and other organisations to increase its bargaining power (Knoesen 2001).

During this process of constitutional review, the National Party objected to specific mention of sexual orientation in the document (Rights of homosexuals 
protected in military 1995). The gay rights provision was opposed most strongly by the African Christian Democratic Party (ACDP), which argued that homosexuality was anti-family, anti-Christian and anti-African (Cock 2002:11). Graeme Reid, also the founder of the Gay and Lesbian Archives at the University of Witwatersrand, remembered that there was some discussion in the media at this time about the implications of fully integrating gays and lesbians into the military. "Some senior military people were interviewed [by the media]," Reid observed, "and there was just the beginning of what could have been a large public debate" regarding gay integration (Reid 2002). Wary of stirring up this opposition, the gay rights lobby backed off from determining what the policy would mean in every manifestation (including the military) and focused its energy on preserving the gay rights clause in the final Constitution. "The strategy was," according to Reid, "to keep sexual orientation in the final Constitution and then let the courts uphold the Constitution" (2002).

In 1996, the new Constitution was adopted with an equality provision that read that "the state may not unfairly discriminate against anyone on one or more grounds, including race, gender, sex, pregnancy, marital status, ethnic or social origin, colour, sexual orientation, age, disability, religion, conscience, belief, culture, language, and birth ..." (Heinecken 1999b:2). After the adoption of the Constitution, both state and non-state actors worked to bring various state policies and laws in line with the Constitution; the South African government committed itself to "reform economic and social conditions for the majority of South Africans left wanting by the apartheid regime" (South African Commission on Human Rights 1999:page number).

This mandate touched all aspects of the South African government, including the SADF, which was reconstituted by the new government as the South African National Defence Force. The SANDF integrated former enemies - the various armies and guerrilla forces who battled apartheid and members of the former SADF - into a single body. According to the Special Rapporteur of the South African Commission on Human Rights, "[t]he government's objective is to destroy the army's symbolic identity as an essential pillar of apartheid and turn it into a melting pot of national unity and a law-abiding democratic institution" (South African Commission on Human Rights 1999:page number).

The SANDF was now an 'all-volunteer' force that attempted to be more representative of South African society. In 1996, the Minister of Defence published the White Paper on National Defence for South Africa. This document stated that "to secure the legitimacy of the armed forces, the Department of Defence is committed to the goal of overcoming the legacy of racial or gender discrimination" 
(Heinecken 2002). While the South African military was historically mostly white, the integration of predominantly black homeland armies and guerrilla forces reversed the racial balance of the SANDF. This process was challenging for the SANDF. "Not only did the SANDF integrate former forces with strong political loyalties and from diverse military backgrounds, but nine ethnic and eleven language groups, each with their own culture and traditions" (Heinecken 1999a:193).

Women also occupied a different place in the SANDF than they did in the SADF. While women were admitted into the permanent force after 1970, they were excluded from combat roles. The SADF remained heavily patriarchal and women were integrated into the South African military at much lower levels than in the USA, for example. After the adoption of the new Constitution, the military changed course, forbidding any job discrimination on the basis of gender, encouraging women to achieve leadership positions within the SANDF and allowing women to be employed in combat roles, a position that was very controversial (Cilliers \& Heinecken 2000:254; Heinecken 1999a:198). ${ }^{4}$

In order to bring its governing principles fully in compliance with the new Constitution, the Ministry of Defence embarked on a defence review process in which public input on all facets of its operating procedures and policies was invited. There was one day during the review process, according to Heinecken, "when there was very intense discussion about what the gay rights clause would mean in each and every sector of military life" (Heinecken 2002). The issue of homosexuality in the military generated little public debate prior to the adoption of the new Constitution, ${ }^{5}$ and despite some initial concerns, "the Department of Defence considered the [integration of homosexuals] as a fait accompli," said Evert Knoesen, Director of the Lesbian and Gay Equality Project (formerly the National Coalition for Lesbian and Gay Equality) (Knoesen 2002). Thus, the policy change came from

${ }^{4}$ According to Cilliers and Heinecken (2000:254), "[d]espite formal provisions, both the military and the general population still express strong resistance to women's serving in combat positions. In a recent public-opinion survey, 59 percent of respondents felt that women should not be allowed to do combat duty or serve on the front line. Because of ingrained cultural attitudes and stereotypes in South African society, women still are regarded as unsuited for positions that may involve risk or danger. Some time will pass therefore before women serving in the South African military are really and fully integrated into all combat functions".

5 For one thing, according to Reid, "the terms of the debate were so different because there was so much resistance to being in the military [generally]" during the apartheid era (2002). 
within the Department of Defence (DOD) itself. "The DOD decided to make its own policy," said SANDF Colonel Jan Kotze, "taking its cue from the stipulations of the Constitution" (Kotze 2001).

The policy on sexual orientation was included as part of the DOD's Policy on Equal Opportunity and Affirmative Action, which was initially promulgated in 1998, then reviewed and readopted in 2002 (Kotze 2003). ${ }^{6}$ Under this policy, recruits were not questioned about their sexual orientation and the SANDF was officially unconcerned about lawful sexual behaviour on the part of its members. However, as Heinecken observed,

[w]hile no action will be instituted against a member of the SANDF for being a homosexual, the policy still remains that any sexually atypical or immoral behavior that could detrimentally affect esprit de corps or morale, or cause emotional stress, thereby affecting military discipline or effectiveness, is subject to disciplinary action and the perpetrator may be punished with detention, reprimanded, fined, or discharged. This policy applies to unacceptable sexual behavior by both heterosexual and homosexual members. (Heinecken 1999b:2)

\section{Implementation, monitoring and additional initiatives}

In order to carry out the new SANDF policies regarding women, black people and sexual minorities, the Defence Minister established an Equal Opportunity and Affirmative Action Directorate. Major-General Jackie Sedibe was appointed to lead the Directorate. Sedibe was the first black female general in the SANDF. Sedibe and her staff were charged with developing, researching, evaluating and monitoring all affirmative action and equal employment programmes of the SANDF, including those governing sexual orientation. The SANDF employed a variety of strategies to integrate gays and lesbians into the SANDF. Knoesen, who monitored the military closely, stated that his impression was that the DOD was very serious about this issue, and that they put a lot of money and effort into it at the time (Knoesen 2002). This effort included the following initiatives:

Most fundamentally, and in the spirit of the Truth and Reconciliation process in South Africa more generally, the SANDF was willing to examine past abuses against gays and lesbians. While the Aversion Project study chronicled incidents of chemical castration, aversion shock therapy and hormone and drug treatment, the DOD was supportive of the research and helpful in the research

6 This was the South African military's first policy on equal opportunity and affirmative action (Heinecken 1999a:191). 
process. When the study was completed, the research team conducted a workshop that included the Ministry of Defence, the Military Health Services of the SANDF, the Gay and Lesbian Equality Project, ${ }^{7}$ the Health Professions Council of South Africa, the South African Medical Association and the Centre for the Study of the Violence and Reconciliation (Harvey 2000). According to Reid, the DOD sent very high-level officials from all the different military branches to the meeting. While some have been critical that the military did not push for extradition of the main perpetrator of these acts, according to Reid, "[t]hey listened and took the information seriously". Reid (2002) concluded: "That was what we wanted". After the meeting, Simon Lewin, an investigator on the Aversion Project, told the media, "I feel confident that there is a commitment to putting mechanisms in place to ensure that discrimination and human rights violations on the basis of sexual orientation are prevented in the future" (Harvey 2000).

The commitment of the SANDF to the integration of gays and lesbians was also demonstrated by the fact that the military appointed an openly gay colonel, Jan Kotze, to the Equal Opportunity and Affirmative Action Directorate to monitor the policy. This colonel worked closely with an openly lesbian captain, who was "on the fast track to become the first lesbian officer to hold the equivalent rank of general" in the SANDF (Knoesen 2002). In addition, the DOD created the Minister of Defence's Advisory Board on Employment Equity and Affirmative Action and awarded a permanent seat on this board to a representative of the gay and lesbian community. Both from inside and outside the military, therefore, the SANDF opened channels of communication and solicited feedback from gay and lesbian South Africans.

In general, the policy was carried out as part of broader equal opportunity goals and not separate from it (Knoesen 2002). This was done by means of an annual Equal Opportunities Climate Survey, focus group discussions held at various units, evaluation of the policies by a separate evaluation section, the monitoring of grievances related to equal opportunity and affirmative action, and training and development courses throughout the Department (Kotze 2003). Specifically, the sexual orientation policy was communicated to units and bases through training 'roadshows' and policy workshops, where members of the Equal Opportunity and Affirmative Action Directorate explained policies and discussed diversity issues (Kotze 2003; Modise 2002). The DOD placed equal opportunity advisors at general support bases, who served various military units with regard to human resource issues (Kotze 2003). Finally, the DOD had the South African Human Rights

\footnotetext{
${ }^{7}$ Formerly the National Coalition for Gay and Lesbian Equality.
} 
Commission conduct yearly workshops with senior SANDF officers, a training programme that included an emphasis on sexuality issues (Kollapen 2002).

In addition to training initiatives, the SANDF continued to address inequitable policies. An example of this is a lesbian judge who sued the government in 2001 for the same benefits for her spouse as were available to the spouses of heterosexual judges. The Pretoria High Court found in her favour. Subsequently, the Equality Project, acting through the Minister of Defence's Advisory Board on Employment Equity and Affirmative Action, raised the issue of benefits for gay and lesbian military personnel. In response, the SANDF amended regulations on marital status in the defence force, stating that "marital status now includes the status or condition of being single, divorced, widowed, or in a relationship, whether with a person of the same or the opposite sex, involving reciprocal support in a relationship". Defence regulations that awarded medical and pension benefits to spouses of SANDF personnel were amended to define spouse as "a partner (the partnership being either heterosexual or homosexual) in a permanent lifepartnership, if such a partnership was attested before a Notary Public". After the SANDF implemented its new benefits policies, the Department of Public Service and Administration also began a review of benefits for same-sex partners within the civil service (SANDF ends benefits discrimination 2002; Equal rights for gay soldiers 2002). At the time, 79 same-sex 'life-partners' of DOD employees take advantage of health benefits (Kotze 2003).

In addition, the DOD undertook a major study in 2000 in order to fully assess the environment for gay and lesbian personnel in the DOD. A total of 2648 regular force members completed a lengthy survey. The survey report noted that many respondents were undecided on many survey questions, and that there was often a large disparity between the attitudes of various subgroups within the SANDF regarding gays and lesbians. On many issues, officers, white personnel, personnel from the military medical service (SAMHS) and personnel in the Office of the Secretary for Defence held more pro-gay attitudes than Africans, members of the Army and members with lower ranks (South African Department of Defence n.d.[b]). ${ }^{8}$ Only $24.6 \%$ of the total population agreed/strongly agreed with the statement I feel good about the integration of gays into the military, while $48.3 \%$ disagreed/strongly disagreed and $27.1 \%$ were undecided.

At the time the DOD added sexual orientation to its Policy on Equal Opportunity and Affirmative Action in 1998, there was some sentiment that a separate policy addressing sexual orientation would be necessary. After completing

${ }^{8}$ The SANDF is comprised of four branches: Army, Navy, Airforce and SAMHS. 
the 2000 survey, and in part as a response to it, the Equal Opportunities Chief Directorate sought authority from the Plenary Defence Staff Council to embark on a process of formulating a separate departmental policy dealing with sexual orientation (Kotze 2003). Significantly, the DOD had Colonel Kotze, an openly gay man, draft the new policy on sexual orientation (Knoesen 2002).

\section{Implications of the integration of gays and lesbians into the SANDF}

\section{- Disclosures}

In some ways, the right of gay and lesbian South Africans to serve in the military remained, as Heinecken argues, a "silent right" (Heinecken 1999b). "I don't think we are yet in a place where people in the SANDF can talk about these issues very openly," Heinecken elaborated (Heinecken 2002). There was no mass comingout in the SANDF after the policy change. "It is still not out in the open," said Henry Boshoff, an analyst for the Institute for Strategic Studies, a South African military think-tank. "People are very selective about who they tell" (Boshoff 2002). But Knoesen asserted that some gays and lesbians in the SANDF did come out and subsequently advanced in their careers. In contrast to the apartheid era, gays and lesbians began to perceive of military service as a career option, and new recruits were more open about their sexuality than in the past (Knoesen 2001). Colonel Jan Kotze stated that while the Equal Opportunities section of the DOD did not track the number of gays and lesbians that came out after the policy change (and had no knowledge of the total number of gays and lesbians in the SANDF), the sexual orientation policy was reported in the media and was "thought to have attracted the attention of candidates to the Department as a possible employer - including gays and lesbians" (Kotze 2002). Lewin concurred that "informal discussions with gays and lesbians ... indicated that they feel much more comfortable now that they are protected, and are able to be more upfront about their sexuality" (Lewin 2001). ${ }^{9}$

While efforts made during the course of this study to reach gay and lesbian service members only produced one openly gay service member, his experiences in the SANDF confirm that the new policy established a relatively positive environment for gay personnel. ${ }^{10}$ This man, a captain, was openly gay and the

${ }^{9}$ A very promising parallel case is that of the South African Police Service, which, according to University of Pretoria criminology Professor Aubrie Theron (2002), "has undergone a dramatic transformation since democratization". Theron reports that there is a forum for gay police officers and "in general gay and lesbian officers are accepted without any problems" (2002).

${ }^{10}$ Efforts to reach gay service members included posting a notice on a university list-serv and on a web site for gay South Africans, contacting all major gay 
partner of another soldier in his unit. "It seems like most of the people in the unit have accepted [us]," he commented. "Some people seem to be proud of being friends with gays in the organisation". While this captain attended unit functions with his partner, he described them as 'out' but "not banner waving". But without "banner waving," he said, "if someone does not know my sexual orientation and asks, he or she gets a fair and honest answer" (Captain 2003).

It is clear that the anti-discrimination policy made this captain feel more comfortable in his unit. He reported that he felt proud when the provision against anti-gay discrimination was read in his unit each week as part of the Code of Conduct. Moreover, while this captain stated that he knew of very little blatant discrimination against gays in the SANDF, knowledge that he was protected by the anti-discrimination policy empowered him to deal effectively with the "jokes behind your back". He related the following incident:

About a year-and-a-half ago, one of my subordinates (a straight corporal) reported to me that a major [had] made jokes of me in front of him and junior staff members regarding my sexual orientation. The whole issue is hilarious, as they did not expect my corporal to be loyal and supportive to his section head. He reported it to me. Well I acted by confronting the [commanding officer], stating if I ever hear senior [officers] gossiping and joking about my sexuality behind my back, then I will make an example of them through the legal channels. I only did this to . . . stop the gossiping issue and the improper military practice of discussing a senior in front of juniors.

(Captain 2003)

- $\quad$ Effect on anti-gay attitudes

Numerous military officials reported that there was now "zero discrimination" in the SANDF against gays and lesbians. "No incidents of blatant harassment or discrimination based on sexual orientation . . . or violence against gays and lesbians ... have been reported to Equal Opportunities Chief Directorate since the Policy on Equal Opportunities was adopted," said Colonel Jan Kotze

rights organisations in South Africa and asking virtually all informants whether they knew of anyone who would agree to an anonymous interview by phone or by email. While some gays and lesbians were undoubtedly 'out' in the SANDF, many were out only selectively, and the trust required to disclose personal information of this nature over the phone to a foreigner or stranger proved an insurmountable obstacle. 
(Kotze 2003). This sentiment was echoed by those outside of the military who monitored these issues. Thandi Modise was a Member of Parliament with considerable expertise on military issues as the Chairwomen of the Parliament's Portfolio Committee on Defence in the South African Parliament. "You just don't hear the stories that we used to hear before 1994 of the levels of intolerance for gays," Modise said. "If there are incidents, they are very few and far between . . . because I don't hear about them" (Modise 2002). This sentiment was echoed by Advisor to the Defence Minister, Sue Rabkin. Anti-gay discrimination "certainly hasn't affected anyone I've heard about, and usually these things travel," Rabkin said. "I get quite a lot of information and I haven't heard a peep" (Rabkin 2002).

Evert Knoesen monitored discrimination complaints both in his position on the Minister's Advisory Board and as Director of the Equality Project. After integration, the only complaints he was aware of at the time had dealt with residual discrimination in employment policies - pensions or health benefits, for example. "These issues have all been cleared away," Knoesen stated. While he thought it was possible that gay or lesbian personnel might not report victimisation (harassment or violence) easily, he concluded that "if people are prepared to complain about [pensions or health benefits], then if they had been physically assaulted or something like that we probably would have heard about it, or at least some of it" (Knoesen 2002).

However, for all of these ways in which the integration of gay and lesbian personnel appeared to be successful, the law was still ahead of social attitudes in South Africa. The policy enjoyed very strong support among military and governmental leaders, but there was still a residue of anti-gay sentiment. This sentiment seemed to be concentrated in the following locations:

1) Among an older cadre of soldiers. "You do have people from the old school who have trouble accepting the sexuality of other people," Modise conceded (Modise 2002).

2) Among lower-level management and at the level of the unit (Reid 2002). If there was still a problem, Evert Knoesen concluded, "it is among the lower ranks" (Knoesen 2002).

3) In rural areas and among commanding officers from the homeland armies. How much the culture of the military changed after integration, according to archivist Anthony Manion of the Gay and Lesbian Archives, "depends a lot on where you are in the country at the time" (Manion 2002). Evert Knoesen concurred: "Most of the people who serve in the defence force are from rural and impoverished areas, and they have very little exposure to lesbian and gay issues" (Knoesen 2002). 
- Operational effectiveness

Overall, informants agreed that the integration of gay and lesbian personnel did not have a negative impact on recruitment and retention, morale, unit cohesion or operational effectiveness in the SANDF. Heinecken reported that in the SANDF (as in the USA) commanders found that gay service members conducted themselves professionally and "their sexual preference did not detract from their ability to perform their work successfully" (Heinecken 1999b:5). Modise asserted that "the effect on morale has only been positive because members of the defence force do not have to hide" (Modise 2002). Colonel Jan Kotze concurred, stating that "diversity contributes towards increased morale, unit cohesion and ultimately mission readiness" (Kotze 2002). Colonel Rocklyn Williams, Director of the Programme for Safer Africa, a South African think-tank, and a former SANDF commander, simply concluded that the integration of gays and lesbians into the SANDF had "no impact whatsoever" on operational effectiveness (Williams 2002).

Military experts and outside experts interviewed for this study commonly asserted that the integration of gay and lesbian personnel was more or less a nonissue, dwarfed by challenges of much greater magnitude. The integration of several different forces proved hugely difficult, as did racial and gender integration. ${ }^{11}$ All of this had an impact on mission readiness for the SANDF, "but this is not related to lesbian and gay people," said Knoesen (2002). "When the SANDF was formed there were so many other issues," concurred Heinecken, "integrating seven different forces into one, the end of conscription, racial transformation, and all of these things override the issue of gays and lesbians in the military". She concluded: "This has not been a major issue" (Heinecken 2002). Democratic Party Member of Parliament and Defence Committee member Hendrik Schmidt stated: "Operational effectiveness has been affected by a number of other factors, but I wouldn't isolate [the integration of gays and lesbians] as being one of them" (Schmidt 2003). Colonel Williams agreed: "Gay and lesbian issues are the least of people's worries. The force has had to rise up to the most monumental challenges" (Williams 2002).

\footnotetext{
${ }^{11}$ Heinecken (1999a) reported that the DOD's policy of 'fast-tracking' women, black people and persons with disabilities was controversial. In addition, Heinecken reported that while "formally there is full racial integration in training and posts, there is still a high degree of social segregation among the different racial groups" (Heinecken1999a:194-195).
} 
Mighty Madasa, Member of Parliament and defence spokesperson for the ACDP, speculated that some service members might have had problems accepting gay and lesbian personnel, but he linked these problems to broader diversity issues. Madasa remembered a presentation by the Affirmative Action Directorate of the DOD that "was not specific to sexuality". Madasa recalled that "the presentation did raise an issue, but it was in vague and general terms, that there might be problems, cultural or otherwise, accommodating gay or lesbian soldiers" (Madasa 2002). Similarly, Dr Hussein Solomon, Head of the Unit for African Studies at the University of Pretoria, asserted that older military personnel were less comfortable with gays in the military. "You have many of the younger guys coming in where it is not so much of an issue," Solomon remarked, "but for many of the older guys, my feeling is that they are less open to the whole situation and that they are concerned about cohesion and force morale". That anti-gay attitudes might have had some impact at the level of the unit is indicated by the DOD's 2000 survey, which found that some $42 \%$ of those surveyed agreed with the statement that "gays and lesbians in the military will undermine social cohesion" (South African Department of Defence n.d. [b], emphasis mine). (However, it should be noted that the survey did not ask if gays and lesbians had, in fact, undermined social cohesion, despite the fact that gays and lesbians had been serving openly for four years at the time of the survey.)

While Democratic Party Member of Parliament James Selfe (a former member of the Portfolio Committee on Defence) agreed that there were some soldiers who were unhappy about gays in their units, he stated that these attitudes had no impact on mission readiness or operational effectiveness. Selfe (2003) explained:

I happen to know that there is an old Guard within the SANDF . . . who have what might be called an attitude problem with regard to integrating gays and lesbians into the defence force. I think these people disapprove of the policy, they find it irritating or offensive. But I don't think that this would affect the operational effectiveness of the defence force. It is a disciplined environment. Your personal feelings are less important than might be the case in other organisations. Orders are orders and you have to make the best job of it.

Other informants stated that gay integration had very little impact on mission readiness or operational effectiveness because of the relatively small number of soldiers involved. (As a point of contrast, the South African military went from being a predominantly white to a predominantly black force in a matter of a 
few years.) Colonel Williams at the time concluded that "because most gays in uniform keep their sexual orientation to themselves, it is not something that surfaces very often" (Williams 2002). Henry Boshoff concurred that the integration of gays and lesbians into the SANDF "has had almost no impact because it is a small group of people". Similarly, Colonel Raymond Marutle, former Military Attaché at the South African Embassy in Washington, DC, assessed the impact of the new policy on gays and lesbians on the SANDF as "none whatsoever", and attributed this to the fact that the "percentage of gays and lesbians [in the SANDF] is low" (2002). Boshoff further argued that the integration of gay and lesbian service members was not disruptive because the policy "has been implemented in a very professional and discrete manner" (Boshoff 2002). Marutle agreed that "there is no overall negative picture that one could paint of this policy" and that both "non-gays and gays are happy with this policy" (Marutle 2002).

As a result, there was virtually no public opposition to the policy integrating gays and lesbians into the SANDF. Even the ACDP, which spearheaded opposition to the inclusion of sexual orientation in the Constitution and was vocal in the past in its opposition to gays in the SANDF, retreated from this position. "We don't have a problem with gays and lesbians in the SANDF," said Mighty Madasa, "everyone has a right to work" (Madasa 2002). Asked to identify other political actors in South African who oppose the open service of gays and lesbians in the military, Madasa stated: "There aren't any". ${ }^{2}$

\section{Overall assessments of integration of gays and lesbians into the SANDF}

No other country in the world has a constitution that protects gays and lesbians from discrimination. As a result of this constitutional protection, postapartheid South Africa has witnessed greater public openness about homosexuality. But despite this, South African anti-gay attitudes inherited from both Calvinistic Afrikaner culture and traditional African culture still exert a strong influence on South African society. Most of the people interviewed for this study stressed the homophobic nature of South African society. Despite the Constitution, "homophobia is intense and widespread in post Apartheid South Africa," Cock wrote. "Gays and

\footnotetext{
${ }^{12}$ Madasa's conclusion confirmed the study's own attempts to solicit opinions from those who opposed the policy. Informants were asked to identify potential interviewees who publicly opposed the policy. Most commonly, informants could not identify parties opposed to gay or lesbian service. In a few cases (and in the print media) the ACDP was identified as advocating anti-gay policies.
} 
lesbians continue to be denied cultural recognition and are subject to shaming, harassment, discrimination, and violence" (Cock 2002).

Anti-gay attitudes are manifested in several arenas. First, gays and (especially) lesbians are the victims of intense violence, often sexual assault intended "to cure them" (Duguid 2002). Second, legal prohibitions against gays existed and were enforced. Laws that deemed sodomy an offense punishable by life in prison remained on the books until 1998. And, in contrast to the situation in the USA, the South African sodomy laws were not just symbolic statements of anti-gay prejudice. $^{13}$ There were up to 200 sodomy convictions per year in South Africa well into the 1990s. Those in the military were especially vulnerable to prosecution under sodomy laws (McNeil 1998). Third, even after laws have changed, anti-gay attitudes still permeate many aspects of South African culture. This is especially true in rural South Africa, where "homosexuality is still believed by many to be the work of the devil" (Duguid, 2002).

Many commentators asserted that while attitudes among white South Africans regarding homosexuality are more like that of many Europeans, "black society has deep homophobic streaks" based not only on religion but on the importance of reproducing the family line (McNeil 1997). "Homosex is not in Black culture" read a banner outside the courtroom at Winnie Mandela's infamous 1991 kidnapping and assault trial. ${ }^{14}$ While there is some truth to these racial distinctions, they are over-stated (Conway 2002). According to Sanders, "[i]n pre-colonial times situational same sex activities were known to exist in royal residences and within the military. Of more recent origin are those encountered in industrial mine compounds and within prison confines" (Sanders 1997:101). Some black townships have even begun to hold pageants like "Miss Gay Soweto". "It is often stated that black culture in South Africa is homophobic," Conway remarked, "but deeper investigation reveals that this is a simplistic assumption" (Conway 2002).

The efforts of the SANDF to integrate gays and lesbians must be assessed in light of the larger culture. "The defence force is a reflection of the broader

${ }^{13}$ By stating that American sodomy laws are primarily symbolic, we do not mean to negate the fact that they are occasionally enforced, as in the Bowers $v$. Hardwick case, or more recently, Lawrence et al. v Texas.

${ }^{14}$ Sanders explained that "[i]n her defence on the charges brought against her, Mrs Mandela put forward that she had ordered four black youths to be removed from a Soweto Methodist [church] to protect them from alleged sexual abuse by the ... European minister. [The case was constructed as] simply a matter of the 'good African mother' saving her 'children' from the homosexual advances of a 'bad European father'” (Sanders 1997:100). 
society," commented Kollapen, Director of the South African Human Rights Commission, "and can't divorce societal problems" (Kollapen 2002). While some in the gay community professed disappointment at the level of anti-gay sentiment in the military, others felt that, given the military's history on the issue, significant progress had been made.

The overall assessment of those interviewed for this study was that the SANDF policy on the integration of sexual orientation was a success, even if future work needed to be done by the DOD to ensure that the SANDF was an environment in which gays and lesbians felt comfortable and wanted to work. Kollapen stated that the policy was successful in that it "aligned the military's policy with the Constitution" and that it provides a clear, understandable benchmark "against which acts of discrimination can be judged" (Kollapen 2002). Reid concurred that the policy "changed the parameters" such that "it is not okay to be overtly discriminatory" (Reid 2002). Further, Kollapen credited the new policy with creating an atmosphere where issues of gay and lesbian equality can be taken up within the SANDF. "Previously there wasn't even room for this discussion," Kollapen asserted (2002).

Moreover, while more can be done to increase tolerance within the SANDF, major inroads have been made. "A significant number of Defence Force members are now willing to serve with lesbian and gay personnel," said Knoesen, "and the majority of the officer core has accepted this change" (2002). Perhaps most significantly, the policy made a difference in the lives of gay and lesbian personnel. "I think that the policy has had a strong impact," Reid asserted. "Having official protection makes all the difference" (Reid 2002). Knoesen (2002) emphasised not only the magnitude of the transformation the military has undergone, but also the short time span in which it took place:

Eight years ago it was illegal to be in the Defence Force and be a homosexual. Now it is illegal to discriminate against someone who is homosexual in the Defence Force. The kind of impact that this has on the emotional experience of a homosexual in the Defence Force is very significant. It takes you from the experience of being unwanted to the experience of self-validation.

According to Colonel Williams, the policy was limited in that it was more reactive than proactive. The policy "served as a deterrent," Williams said, but did not eliminate what remained "a very masculine culture" in the military (Williams 2002). The problem that remained, according to Cock, was "not at the level of formal policy and law, but at the level of social attitudes" (Cock 2002). While the 
SANDF very successfully created a formal culture that prohibited discrimination and harassment against gay and lesbian personnel (and indeed went further in

ensuring that DOD policies were equitable for heterosexuals and homosexuals), the DOD had yet to fully eliminate anti-gay attitudes in the military's informal culture.

\section{References}

Asher, J.B. 2002. South African military fights gay order. 365gay.com Newscenter, 2 February.

Boshoff, H. 2002. Personal interview. Pretoria.

Captain.2003.Anonymous interview.

Cilliers, J. \& Heinecken, L. 2000. South Africa: Emerging from a time warp. In C.C. Moskos, J.A. Williams \& D.R. Segal (eds.). The post modern military: Armed forces after the Cold War. New York: Oxford University Press: 242264.

Cock, J.2002. Personal interview. Johannesburg.

Cock, J. 2003.Engendering gay and lesbian rights: The equality clause in the South African Constitution. Forthcoming in Women's Studies International Forum.

Conway, D. 2002. Personal interview. Grahamstown.

Conway, D.J. 2000. In the name of humanity, can you as a woman, as a mother, tolerate this? Gender and the militarisation of South Africa. Unpublished master's thesis, University of Bristol, Bristol.

Duguid, S. 2002. Real lives: I love a man in uniform. The Guardian, 31 October.

Equal rights for gay soldiers.2002. Mail \&Guardian, 11 January.

Gevisser, M. \& Cameron, E. (eds.).1995. Defiant desire: Gay and lesbian lives in South Africa. New York: Routledge.

Harvey, M. 2000. Shock report sparks health, military focus on gay rights. Africa News, 19 December.

Heinecken, L. 1998. Social equality versus combat effectiveness: An institutional challenge for the military. African Security Review 7(6):3-16.

Heinecken, L. 1999a. Managing diversity in an unequal society: The challenges facing the South African National Defence Force. In J. Soeters\& J. van der 
Meulen (eds.). Managing diversity in the armed forces: Experiences from nine countries. Tilburg: Tilburg University Press: 187-210.

Heinecken, L. 1999b. The silent right: Homosexuality and the military. African Security Review 8(5):43-55.

Heinecken, L. 2002. Personal interview. Saldanha.

Knoesen, E. 2001. Personal interview. Yeosville.

Knoesen, E. 2002. Personal interview.

Kollapen, J. 2002. Personal interview. Johannesburg.

Kotze, J. 2001. Personal interview. Pretoria.

Kotze, J. 2003. Personal interview. Pretoria.

Lewin, S. 2001. Personal interview. London.

Madasa, M. 2002. Personal interview. CapeTown.

Manion, A. 2002. Personal interview. Johannesburg.

Marutle, R. 2002. Personal interview. Washington, DC.

McNeil, D.G. 1997.In a new South Africa, old anti-gay bias persists. New York Times, 17 November.

McNeil, D.G. Jr. 1998. South Africa strikes down laws on gay sex. New York Times, 10 October.

Modise, T. 2002. Personal interview. Cape Town.

Pollecut, L. 2003.Personal interview. Johannesburg.

Rabkin, S. 2002. Personal interview. CapeTown.

Reid, G. 2002. Personal interview. Amsterdam.

Sanders, A.J.G.M. 1997.Homosexuality and the law: A gay revolution in South Africa. Journal of African Law 41(1):100-108.

SANDF ends benefits discrimination. 2002. National News: Lesbian and Gay Equality Project, 17 January. Johannesburg.

Schmidt, H. 2003. Personal interview. CapeTown.

Selfe, J. 2003.Personal interview. CapeTown. 
South African Commission on Human Rights.1999. Report of the Special Rapporteur on Racism, Racial Discrimination, Xenophobia and All Forms of Discrimination. Johannesburg.

South African Department of Defence.1996.Defence in a Democracy: White Paper on National Defence for the Republic of South Africa.Pretoria.

South African Department of Defence.2002a. Department of Defence Policy on Equal Opportunity and Affirmative Action. Pretoria.

South African Department of Defence. N.d.(b). Results of the Study on the Integration of Gays and Lesbians in the DOD. Pretoria.

Theron, A.2002. Personal interview. Pretoria.

Van Zyl et al. 1999. The Aversion Project: Human rights abuses of gays and lesbians in the SADF by health workers during the apartheid era. Cape Town: Simply Said and Done.

Williams, R. 2002. Personal interview. Pretoria. 